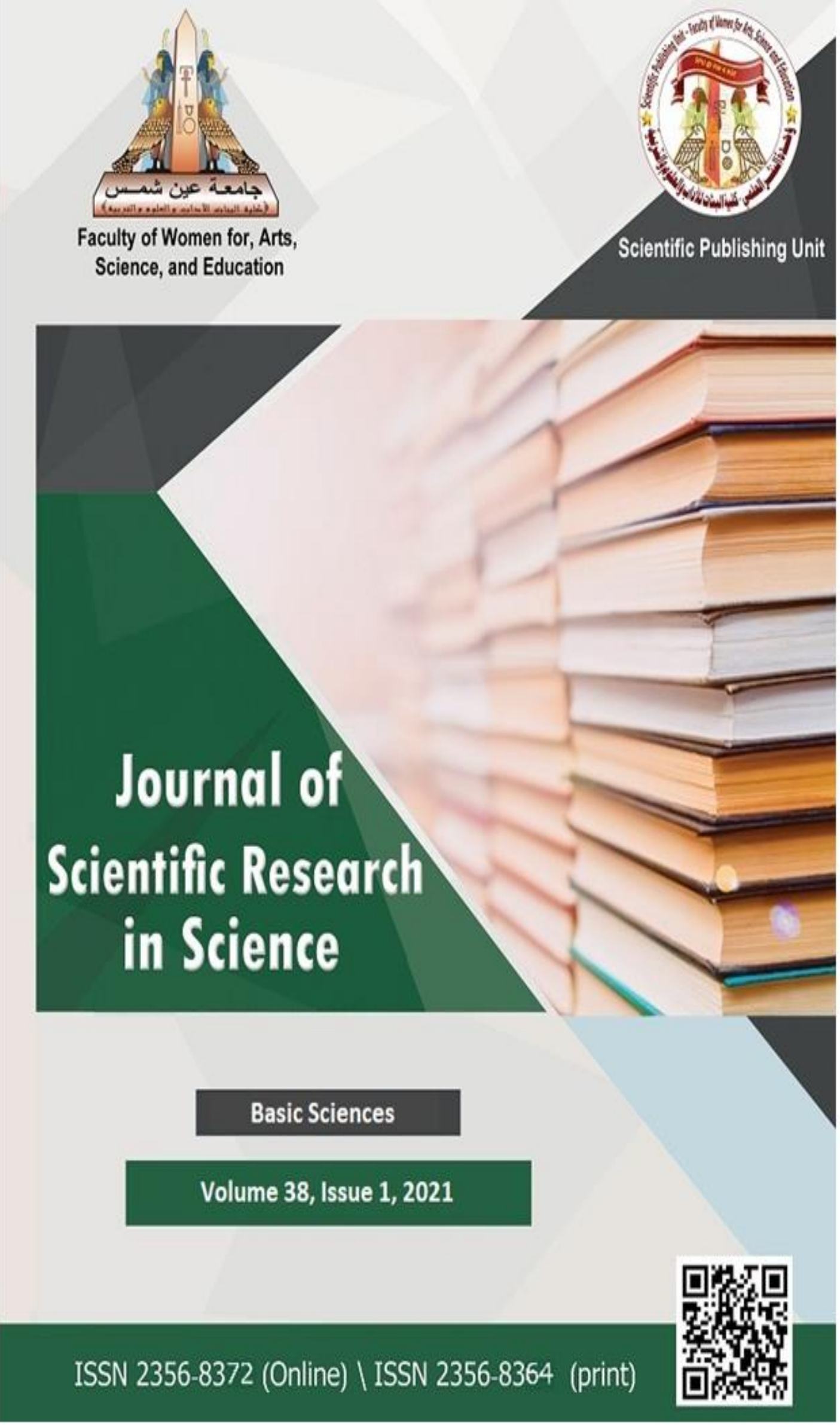




\begin{tabular}{|c|c|c|}
\hline 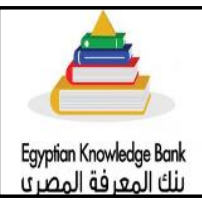 & $\begin{array}{l}\text { Contents lists available at EKB } \\
\text { Journal of Scientific Research in Science } \\
\text { Journal homepage: https://jsrs.journals.ekb.eg/ }\end{array}$ & 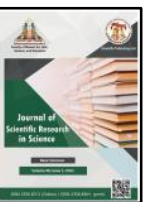 \\
\hline
\end{tabular}

\title{
Structural Characterization, thermal studies, fluorescence and optical properties of metal carbonyl derivatives of $\mathrm{N}_{2} \mathrm{O}_{2}$ Schiff Base
}

\author{
Aml A. A. Awad", Doaa A. Nassar and Omyma A. M. Ali
}

Chemistry Department, Faculty of Women for Arts, Science and Education, Ain Shams University, Cairo, Egypt.

\begin{abstract}
A series of four binuclear complexes $\left[\mathrm{Cr}_{2}(\mathrm{CO})_{2} \mathrm{~L}_{2}\right](1),\left[\mathrm{Mo}_{2} \mathrm{O}_{4}(\mathrm{~L})_{2}\right](2)$, and $\left[\mathrm{W}_{2} \mathrm{O}_{4}(\mathrm{~L})_{2}\right]$ (3) $\left[\mathrm{Mo}_{2} \mathrm{O}_{5}(\mathrm{CO}) \mathrm{L}\right] \cdot \mathrm{H}_{2} \mathrm{O}$ (4) were synthesized from the reaction of $\left[\mathrm{M}(\mathrm{CO})_{6}\right](\mathrm{M}=\mathrm{Cr}$, Mo and $\mathrm{W})$ with 6,6'-(([1,1'-biphenyl]-4,4' diylbis(azaneylylidene $\left.)\right)$ bis(methaneylylidene)) bis(2,4-dichlorophenol) $\mathrm{H}_{2} \mathrm{~L}$ in THF. The structures of the ligand and its complexes were characterized using elemental studies, IR, mass, UV-vis and ${ }^{1} \mathrm{H}$ NMR spectroscopy. Magnetic measurements showed diamagnetic properties for molybdenum and tungsten complexes and paramagnetic character for chromium complex. The thermal analyses for all metal complexes were also determined by the thermogravimetry technique. The thermodynamics parameters of complexes were calculated. Spectroscopic data revealed that $\mathrm{H}_{2} \mathrm{~L}$ was coordinated as a tetradentate ligand through two imine nitrogen and two deprotonated phenolic oxygen atoms. The Schiff base ligand $\left(\mathrm{H}_{2} \mathrm{~L}\right)$ and its complexes displayed fluorescence properties and can potentially serve as photoactive materials. The values of optical band gap energy $\left(E_{g}\right)$ of the prepared complexes suggested that these compounds could be used as semiconductors.
\end{abstract}

\section{Keywords}

Benzidine; Metal Carbonyl Complexes; Fluorescence; Optical Properties

\section{Introduction}

Transition metal complexes containing NO play a significant role in a range of uses and applications, from types of synthetic work to physicochemical work [1] and biochemically related metal complex studies [2]. They're often used as photosensitizers, catalysts and coordinating polymers [3-5] and have established a broad variety of applications [6-7]. On the other hand, complexes containing $\mathrm{C}=\mathrm{O}$ being essential

*Corresponding author: Aml A. A. Awad, Chemistry Department, Faculty of Women for Arts, Science and Education, Ain Shams University, Cairo, Egypt.

E-mail: amalade1269@gmail.com 
intermediates in the combination of effective coordination compounds [8-10]. Also, these complexes are of great structural importance as well as commercial, catalytic, epoxidation, catalytic activity in olefin hydrogenation and photochromic effects. [1112]. Also, transition complexes synthesized from Schiff bases including donor electrons, nitrogen and oxygen such as derivatives of benzimidazole, thiazole, pyridine, pyrazolone, hydrazine, p-fluorobezaldehyde play an essential part in biological systems [13-18]. Our attention in the investigation of metal carbonyl reactions with Schiff bases often brought us to research the reactions of $\mathrm{M}(\mathrm{CO})_{6}(\mathrm{M}=\mathrm{Cr}$, Mo and $\mathrm{W})$ to Schiff Base $\left(\mathrm{H}_{2} \mathrm{~L}\right)$.

\section{Experimental}

\subsection{Materials}

$\mathrm{M}(\mathrm{CO})_{6}(\mathrm{M}=\mathrm{Cr}$, Mo and W), 3,5-Dichlorosalicylaldehyde and benzidine were purchased from Aldrich and used without purification.

\subsection{Instrumentation}

The ligand and its metal complexes were analyzed by elemental analysis (Perkin-Elmer-2400 CHN elemental analyzer) and mass spectrometry (JEOL JMS-AX 500 spectrometer). Infrared measurements were obtained as $\mathrm{KBr}$ plates using a Shimadzu 8000 FT-IR spectrometer. The ${ }^{1} \mathrm{H}$ NMR spectra were registered by using $\mathrm{d}^{6}$ DMSO as a solvent and therefore, the BRUKER five hundred $\mathrm{MHz}$ photometer exploitation TMS as enclosed a reference. Magnetic measurements in the solid state (Gouy method) were carried out on a Sherwood magnetic susceptibility balance. The TG and DTG analysis techniques were recorded at a worming rate of ten ${ }^{0} \mathrm{C} /$ min underneath a gas atmosphere employing a Shimadzu DT-50 thermal analyzer. The luminescent characteristics of the ligand and its compounds analyzed using the LS50B Jenway 6270 Fluorimeter.

\subsection{Synthesis of the Schiff base $6,6^{\prime}-\left(\left(\left[1,1^{\prime}-\right.\right.\right.$ biphenyl $]-4,4^{\prime}-$ diylbis(azaneylylidene))bis(methaneylylidene))bis(2,4-dichlorophenol) $\left(\mathrm{H}_{2} \mathrm{~L}\right)$}

3,5-di-chlorosalicylaldehyde $(0.38 \mathrm{~g}, 2 \mathrm{mmol})$ was added to a solution of benzidine $(0.18 \mathrm{~g}, 1 \mathrm{mmol})$ in methyl alcohol and the mixture was stirring at room temperature. After one-hour, an orange precipitate formed, filtrated off and washed several times with methanol and then left to dry over $\mathrm{CaCl}_{2}$. 


\subsection{Synthesis of complexes}

\subsubsection{Synthesis of $\left[\mathrm{Cr}_{2}(\mathrm{CO})_{2} \mathrm{~L}_{2}\right](1),\left[\mathrm{Mo}_{2} \mathrm{O}_{4} \mathrm{~L}_{2}\right](2)$ and $\left[\mathrm{W}_{2} \mathrm{O}_{4} \mathrm{~L}_{2}\right](3)$ complex}

A mixture of $\mathrm{M}(\mathrm{CO})_{6}(\mathrm{M}=\mathrm{Mo}$ and $\mathrm{W})$ and ligand, $\mathrm{H}_{2} \mathrm{~L}$ in $30 \mathrm{ml} \mathrm{THF}$ was exposed to sunlight irradiation. After 24 hours, the color of the mixture of (1) was changed from orange to red, While the color of (2) and (3) was changed from orange to brown the color of the reaction mixture. Then, the solvent was evaporated. The solid complexes were isolated and washed by petroleum ether.

\subsubsection{Synthesis of $\left[\mathrm{Mo}_{2} \mathrm{O}_{5}(\mathrm{CO}) \mathrm{L}\right] . \mathrm{H}_{2} \mathrm{O}(4)$ complexes}

A mixture of $\mathrm{Mo}(\mathrm{CO})_{6}$ and ligand, $\mathrm{H}_{2} \mathrm{~L}$ in $30 \mathrm{ml}$ THF was refluxed in the air for $6 \mathrm{~h}$. The color of the solution of was changed from orange to dark green. The solid complex was obtained by evaporation of the solvent then washed several times by petroleum ether.

\section{Results and discussion}

Elemental analyses, physical properties and mass spectrometry data of the ligand $\left(\mathrm{H}_{2} \mathrm{~L}\right)$ and its complexes were summarized in Table (1). The metal complexes were insoluble in common organic solvents (methanol, ethanol, acetone and chloroform), but soluble in dimethylformamide (DMF) and dimethylsulfoxide (DMSO).

Table1. Physical properties and analytical data of the Schiff base ligand $\left(\mathrm{H}_{2} \mathrm{~L}\right)$ and its metal carbonyl complexes.

\begin{tabular}{|c|c|c|c|c|c|c|c|c|}
\hline \multirow{3}{*}{ Compound } & \multicolumn{2}{|c|}{ Mass Spectrometry } & \multirow{3}{*}{ Color } & \multirow{3}{*}{$\begin{array}{c}\text { Yield } \\
\%\end{array}$} & \multirow{3}{*}{$\begin{array}{l}\text { M.P. } \\
\left({ }^{0} \mathrm{C}\right)\end{array}$} & \multirow{2}{*}{\multicolumn{3}{|c|}{$\begin{array}{c}\text { Elemental analysis } \\
\text { Found (calc.) }\end{array}$}} \\
\hline & \multirow{2}{*}{ Mol.Wt. } & \multirow{2}{*}{$\mathbf{m} / \mathbf{z}$} & & & & & & \\
\hline & & & & & & $\mathrm{C} \%$ & N\% & H\% \\
\hline $\mathrm{H}_{2} \mathrm{~L}\left(\mathrm{C}_{26} \mathrm{H}_{16} \mathrm{~N}_{2} \mathrm{O}_{2} \mathrm{Cl}_{4}\right)$ & $(530.21)$ & $531(\mathrm{P}+)$ & orange & 87.8 & 260 & $\begin{array}{r}58.96 \\
(58.89)\end{array}$ & $\begin{array}{c}5.39 \\
(5.28)\end{array}$ & $\begin{array}{c}3.12 \\
(3.04)\end{array}$ \\
\hline $\mathrm{Cr}_{2} \mathrm{C}_{54} \mathrm{H}_{28} \mathrm{~N}_{4} \mathrm{O}_{6} \mathrm{Cl}_{8}(\mathbf{1})$ & $(1216.41)$ & 1160 & red & 46.2 & $>300$ & $\begin{array}{c}52.23 \\
(52.32)\end{array}$ & $\begin{array}{c}4.43 \\
(4.60)\end{array}$ & $\begin{array}{c}2.31 \\
(2.32)\end{array}$ \\
\hline
\end{tabular}




\begin{tabular}{|c|c|c|c|c|c|c|c|c|}
\hline \multirow{3}{*}{ Compound } & \multicolumn{2}{|c|}{ Mass Spectrometry } & \multirow{3}{*}{ Color } & \multirow{3}{*}{$\begin{array}{c}\text { Yield } \\
\%\end{array}$} & \multirow{3}{*}{$\begin{array}{l}\text { M.P. } \\
\left({ }^{0} \mathrm{C}\right)\end{array}$} & \multirow{2}{*}{\multicolumn{3}{|c|}{$\begin{array}{l}\text { Elemental analysis } \\
\text { Found (calc.) }\end{array}$}} \\
\hline & \multirow{2}{*}{ Mol.Wt. } & \multirow{2}{*}{$\mathbf{m} / \mathbf{z}$} & & & & & & \\
\hline & & & & & & $\mathrm{C} \%$ & N\% & H\% \\
\hline $\mathrm{Mo}_{2} \mathrm{C}_{52} \mathrm{H}_{28} \mathrm{~N}_{4} \mathrm{O}_{8} \mathrm{Cl}_{8}$ (2) & $(1312.27)$ & $1312(\mathrm{P}+)$ & brown & 50.5 & $>300$ & $\begin{array}{r}47.76 \\
(47.59)\end{array}$ & $\begin{array}{c}4.67 \\
(4.26)\end{array}$ & $\begin{array}{c}2.21 \\
(2.15)\end{array}$ \\
\hline $\mathrm{W}_{2} \mathrm{C}_{52} \mathrm{H}_{28} \mathrm{~N}_{4} \mathrm{O}_{8} \mathrm{Cl}_{8}$ (3) & $(1488.03)$ & $1488(\mathrm{P}+)$ & brown & 45.7 & $>300$ & $\begin{array}{r}41.71 \\
(41.69)\end{array}$ & $\begin{array}{l}3.82 \\
(3.76)\end{array}$ & $\begin{array}{r}1.86 \\
(1.98)\end{array}$ \\
\hline $\mathrm{Mo}_{2} \mathrm{C}_{27} \mathrm{H}_{16} \mathrm{~N}_{2} \mathrm{O}_{9} \mathrm{Cl}_{4}$ (4) & $(846.01)$ & $846(\mathrm{P}+)$ & Dark green & 65 & $>300$ & $\begin{array}{l}38.84 \\
(38.33)\end{array}$ & $\begin{array}{l}3.21 \\
(3.31)\end{array}$ & $\begin{array}{r}1.89 \\
(1.90)\end{array}$ \\
\hline
\end{tabular}

\subsection{Mass spectra}

The mass spectra of the ligand and its complexes revealed that the molecular ion peak consistent with their proposed molecular formula (Table 1). The mass spectra of the Schiff base ligand and $\left[\mathrm{Cr}_{2}(\mathrm{CO})_{2} \mathrm{~L}_{2}\right](1)$ and $\left[\mathrm{Mo}_{2} \mathrm{O}_{5}(\mathrm{CO}) \mathrm{L}\right] . \mathrm{H}_{2} \mathrm{O}, 4$ complexes were shown in Fig.1. 


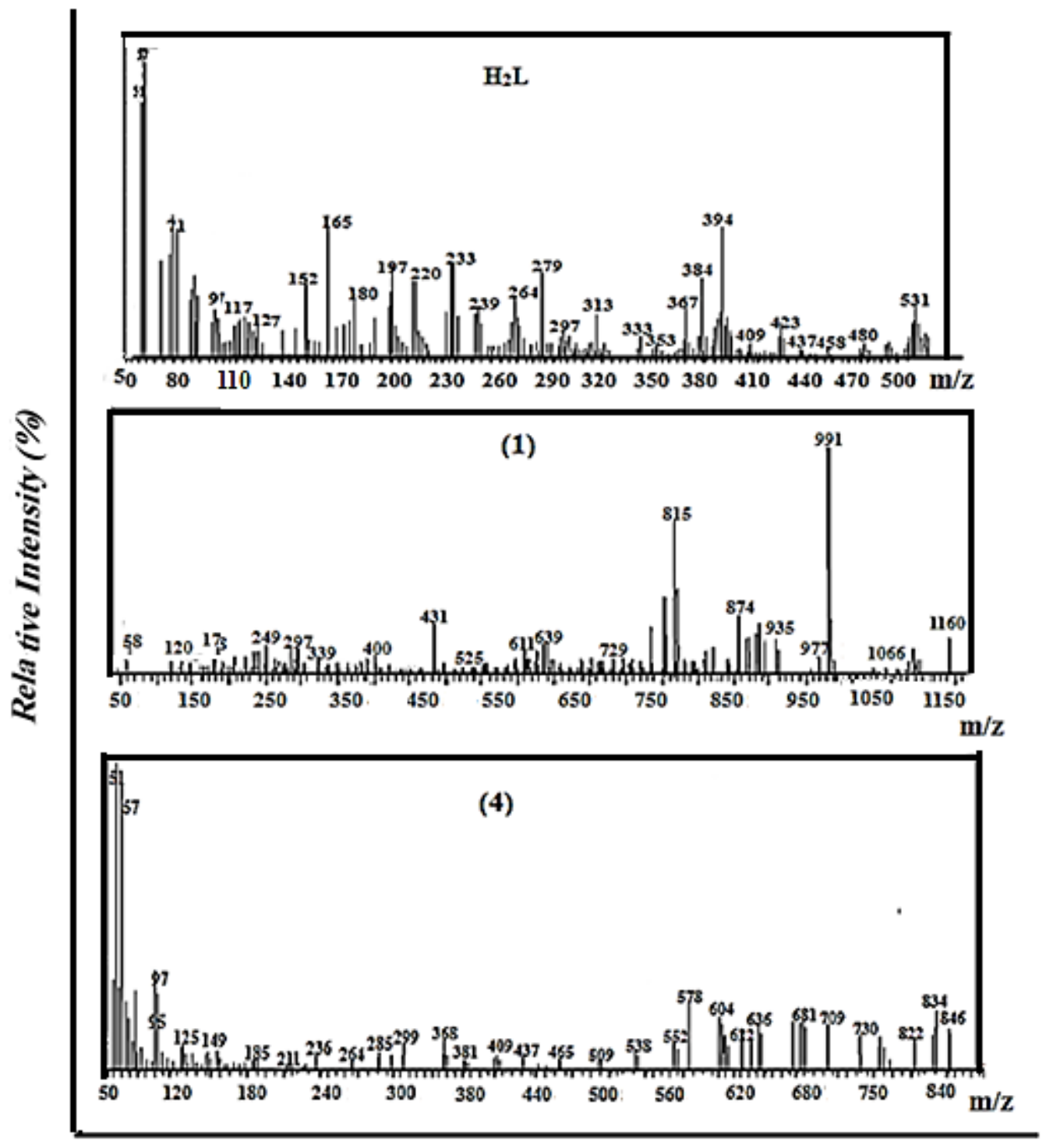

\section{Mass/ Charge}

a

Fig.1. The mass spectra of ligand $\left(\mathrm{H}_{2} \mathrm{~L}\right),\left[\mathrm{Cr}_{2}(\mathrm{CO})_{2} \mathrm{~L}_{2}\right]$ (1) and

$$
\left[\mathrm{Mo}_{2} \mathrm{O}_{5}(\mathrm{CO}) \mathrm{L}\right] \cdot \mathrm{H}_{2} \mathrm{O}(4) \text {. }
$$

\subsection{IR spectra}

The infrared spectrum of the Schiff base ligand $\left(\mathrm{H}_{2} \mathrm{~L}\right)$ displayed broad band at $3384 \mathrm{~cm}^{-1}$ (Table 2) which can be attributed to the phenolic $\mathrm{OH}$ group or $\mathrm{H}_{2} \mathrm{O}$ [19]. This band disappeared in all complexes except complex (4) (Fig.2). The IR spectrum of the ligand $\left(\mathrm{H}_{2} \mathrm{~L}\right)$ showed a band at $1615 \mathrm{~cm}^{-1}$ due to the azomethane $(-\mathrm{HC}=\mathrm{N})$ group [20]. The $\mathrm{C}=\mathrm{N}$ stretching vibration was shifted in the IR spectra of complexes indicating the coordination of ligand with metal throughout azomethine nitrogen atoms [21-22]. 
Also, the C-O stretching band of the $\mathrm{H}_{2} \mathrm{~L}$ was shifted to a higher frequency range indicating coordination through phenolic oxygen [23]. The non-ligand bands observed ranged from 574 to $590 \mathrm{~cm}^{-1}$ due to $\mathrm{M}-\mathrm{O}$ and from 473 to $493 \mathrm{~cm}^{-1}$ due to $\mathrm{M}-\mathrm{N}$ bonds in the infrared spectra of all complexes [24]. The IR spectrum of $\left[\mathrm{Cr}_{2}(\mathrm{CO})_{2}(\mathrm{~L})_{2}\right],(1)$ complex observed band at $1718 \mathrm{~cm}^{-1}$ due to carbonyl group bridging [25]. On the other hand, the IR spectrum of $\left[\mathrm{Mo}_{2} \mathrm{O}_{5}(\mathrm{CO}) \mathrm{L}\right] \cdot \mathrm{H}_{2} \mathrm{O},(4)$ complex displayed two bands at 1718 and $627 \mathrm{~cm}^{-1}$ due to bridging carbonyl group and Mo-O-Mo bridged bond, respectively [26]. Also, the IR spectrum of complex (4) showed stretching frequencies of hydrated water and terminal $\mathrm{Mo}=\mathrm{O}$ bonds for a cis $\mathrm{MO}_{2}$ fragment [27-28]. Both oxo complexes (2) and (3) were showed in the IR spectra two-terminal $\mathrm{Mo}=\mathrm{O}$ vibrations at 915-906 $\mathrm{cm}^{-1}$ and 886-937 $\mathrm{cm}^{-1}$, respectively [29].

Table 2. Most important IR spectral bands of the ligand and its complexes.

\begin{tabular}{|c|c|c|c|c|c|c|c|c|}
\hline \multirow[b]{2}{*}{ Compound } & \multicolumn{8}{|c|}{ IR spectra $\left(\mathrm{cm}^{-1}\right)$} \\
\hline & $\begin{array}{l}\text { v(OH) } \\
/\left(\mathbf{O H}_{2}\right)\end{array}$ & $v(C=N)$ & $v(C-O)$ & $v \mathbf{M}=\mathbf{O}$ & $\begin{array}{c}\text { vM-O- } \\
\text { M }\end{array}$ & $\begin{array}{c}\text { vM-CO- } \\
\text { M }\end{array}$ & vM-O & vM-N \\
\hline $\mathrm{H}_{2} \mathrm{~L}$ & 3384 & 1615 & 1294 & - & - & - & - & - \\
\hline 1 & - & 1599 & 1380 & - & - & 1718 & 590 & 492 \\
\hline 2 & - & 1612 & 1402 & 890,843 & 679 & - & 576 & 474 \\
\hline 3 & - & 1620 & 1380 & 977,813 & 699 & - & 587 & 473 \\
\hline 4 & 3423 & 1636 & 1342 & 959,880 & 627 & 1718 & 574 & 481 \\
\hline
\end{tabular}




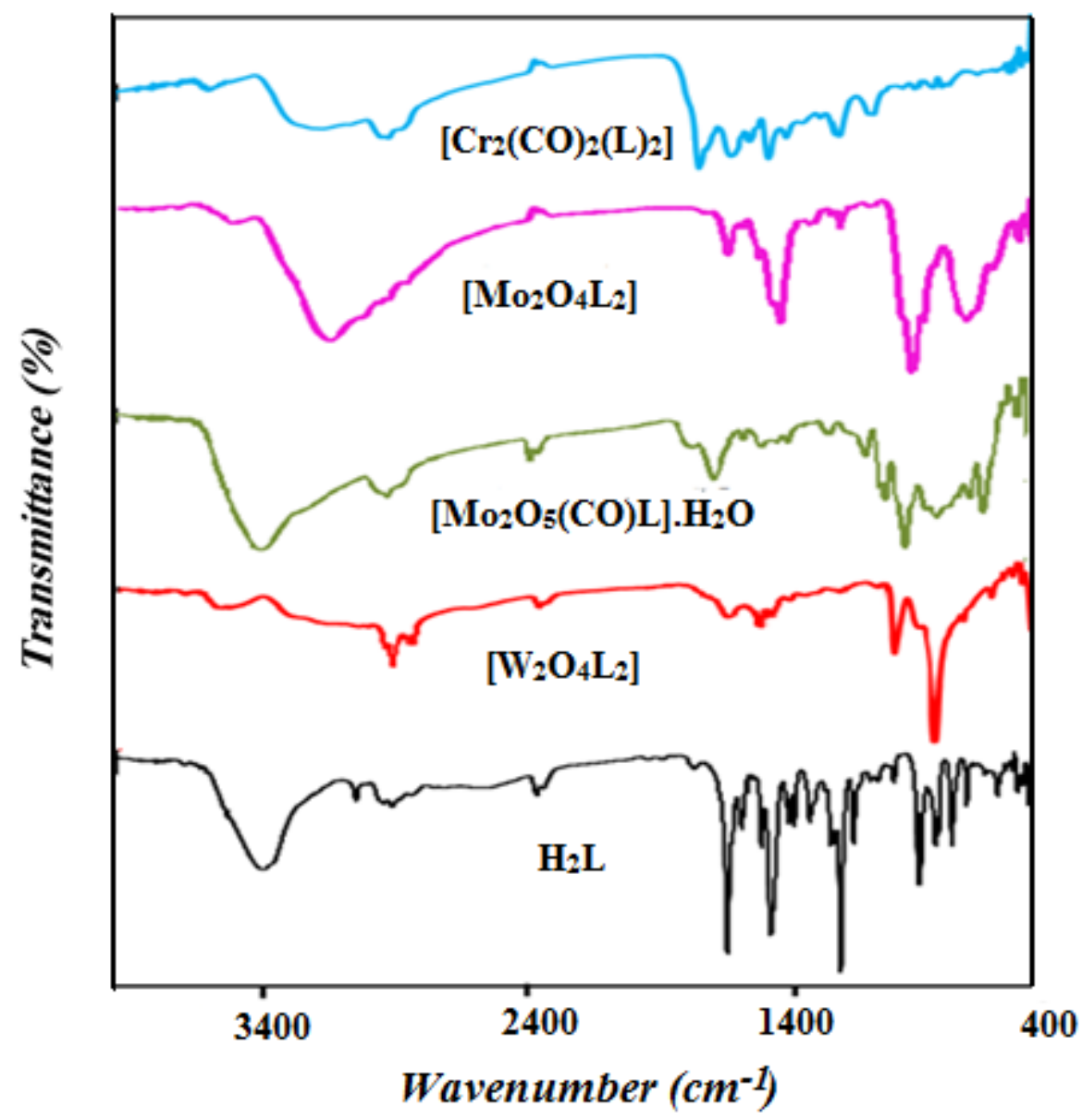

Fig.2. IR spectra of the Schiff base ligand and its complexes.

\section{3. ${ }^{1} \mathrm{H}$ NMR spectra}

The ${ }^{1} \mathrm{H}$ NMR spectra of Schiff base ligand $\left(\mathrm{H}_{2} \mathrm{~L}\right)$ and its molybdenum and tungsten complexes were shown in Fig. 3 and all data are summarized in Table 3. The ${ }^{1} \mathrm{H}$ NMR spectra of the 2, 3 and 4 complexes showed a downfield shift of the azomethine proton $(-\mathrm{HC}=\mathrm{N})$ in comparison with that of the free ligand owing to its coordination only with the central metal atom via azomethane nitrogen [30]. The ${ }^{1} \mathrm{H}$ NMR spectra of the complexes showed an appropriate shift in phenyl protons compared with ligand [31]. ${ }^{1} \mathrm{H}$ NMR spectrum of complex 4 showed a signal consisting of two hydrogen protons allocated to a single water molecule [32]. In comparison, the ${ }^{1} \mathrm{H}$ NMR spectra of molybdenum and tungsten complexes revealed the absence of the hydroxyl proton signal suggesting that the ligand coordinated the metal with proton displacement [33]. 
Table 3. The ${ }^{1} \mathrm{H}$ NMR data (ppm) of the synthesized ligand and its complexes.

\begin{tabular}{|c|c|c|}
\hline Compound & Chemical shift & Assignment \\
\hline \multirow[t]{3}{*}{$\mathrm{H}_{2} \mathrm{~L}$} & 9.06 & $\mathrm{~s}, \mathrm{CH}=\mathrm{N}$ \\
\hline & $7.76-6.68$ & $\mathrm{~m}, 12 \mathrm{Ar} \mathrm{H}$ \\
\hline & 10.10 & $\mathrm{~s}, \mathrm{OH}$ \\
\hline \multirow[t]{2}{*}{2} & 8.82 & $\mathrm{~s}$, of $\mathrm{CH}=\mathrm{N}$ \\
\hline & $8.29-6.67$ & $\mathrm{~m}, 24 \mathrm{Ar} \mathrm{H}$ \\
\hline \multirow[t]{2}{*}{3} & 8.97 & $\mathrm{~s}, \mathrm{CH}=\mathrm{N}$ \\
\hline & $8.69-6.95$ & $\mathrm{~m}, 24 \mathrm{Ar} \mathrm{H}$ \\
\hline \multirow[t]{3}{*}{4} & 8.15 & $\mathrm{~s}, \mathrm{CH}=\mathrm{N}$ \\
\hline & 7.9-6.9 & $\mathrm{m}, 12 \mathrm{ArH}$ \\
\hline & $4.30-4.27$ & $\mathrm{~d}, 2 \mathrm{H}, \mathrm{H}_{2} \mathrm{O}$ \\
\hline
\end{tabular}




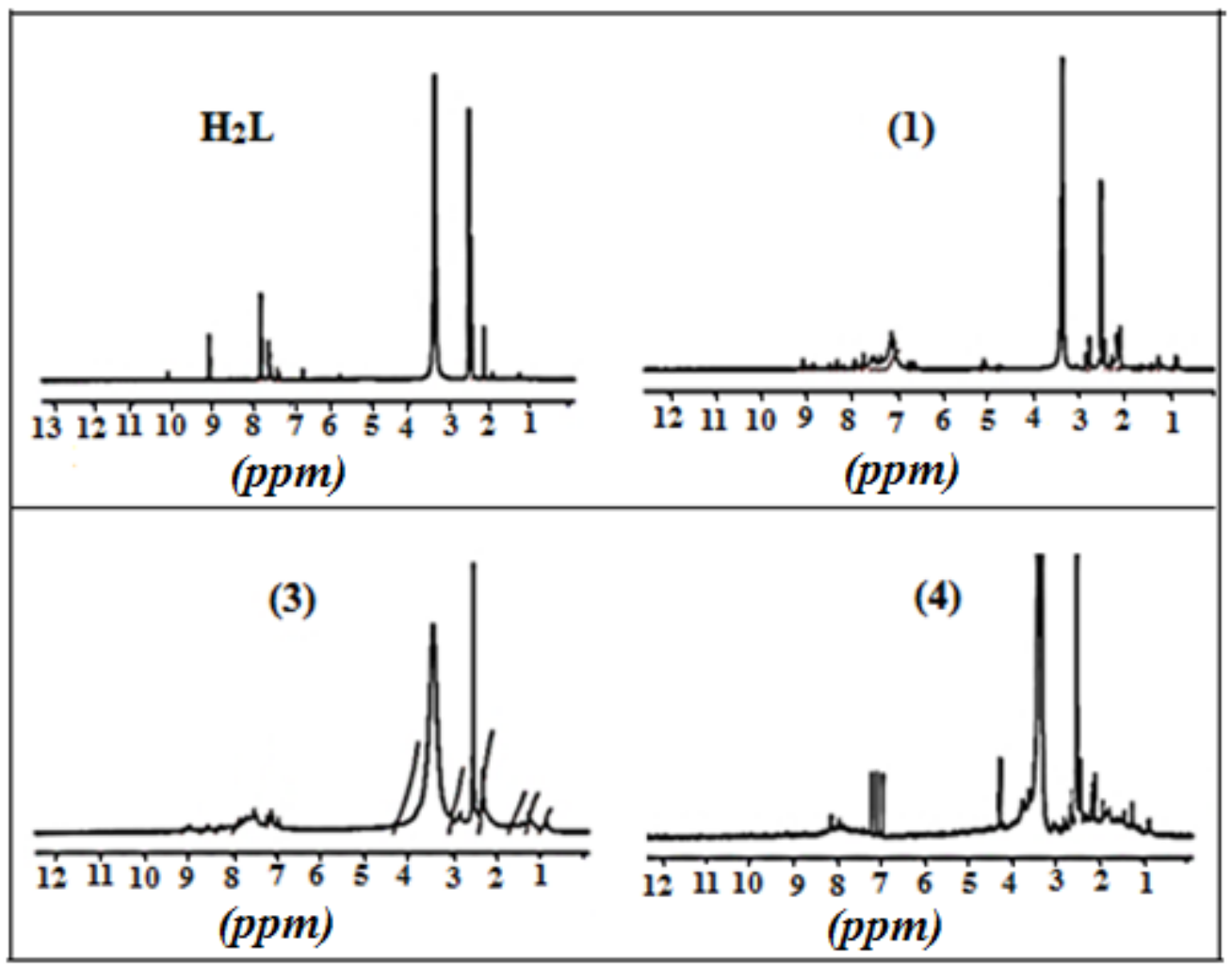

Fig.3. ${ }^{1} \mathrm{H}$ NMR spectra of ligand and its complexes.

\subsection{Magnetic measurements}

The magnetic study of the chromium complex revealed paramagnetic properties. The effective magnetic $\left(\mu_{\mathrm{eff}}\right)$ value of $2.93 \mathrm{BM}$ was close to the spin-only magnetic moment of two unpaired electrons $(2.84 \mathrm{BM})$ in a low spin electronic configuration. Each chromium atom was existed in +2 oxidation state [34].

The results of the spectroscopic analysis were in full alignment with the suggested ligand and its complex structures (Figs. 4-5). The chromium complex, 1 was a binuclear complex with two $\mathrm{Cr}$ atoms bridged by two carbonyl groups. The complex $\left[\mathrm{Mo}_{2} \mathrm{O}_{5}(\mathrm{CO}) \mathrm{L}\right] \cdot \mathrm{H}_{2} \mathrm{O}$ (4) could consist of two Mo atoms was bridged by one oxygen and one carbonyl group and each molybdenum may have +6 formal oxidation states[35]. The two complexes 2 and 3 were binuclear with two $\mathrm{H}_{2} \mathrm{~L}$ ligands bound to the metal by nitrogen and oxygen atoms. Each metal in 2 and 3 could have +6 formal oxidation states with $\mathrm{d}^{0}$ electronic configuration. 


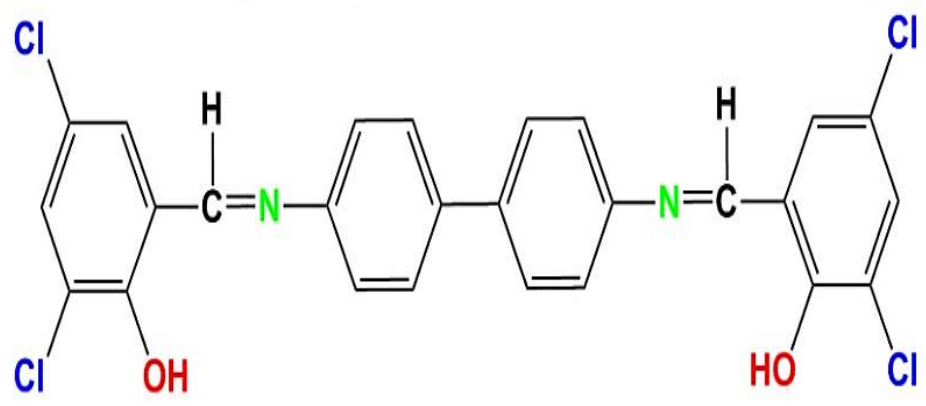

Fig.4. The proposed structure of the $\mathrm{H}_{2} \mathrm{~L}$ ligand.
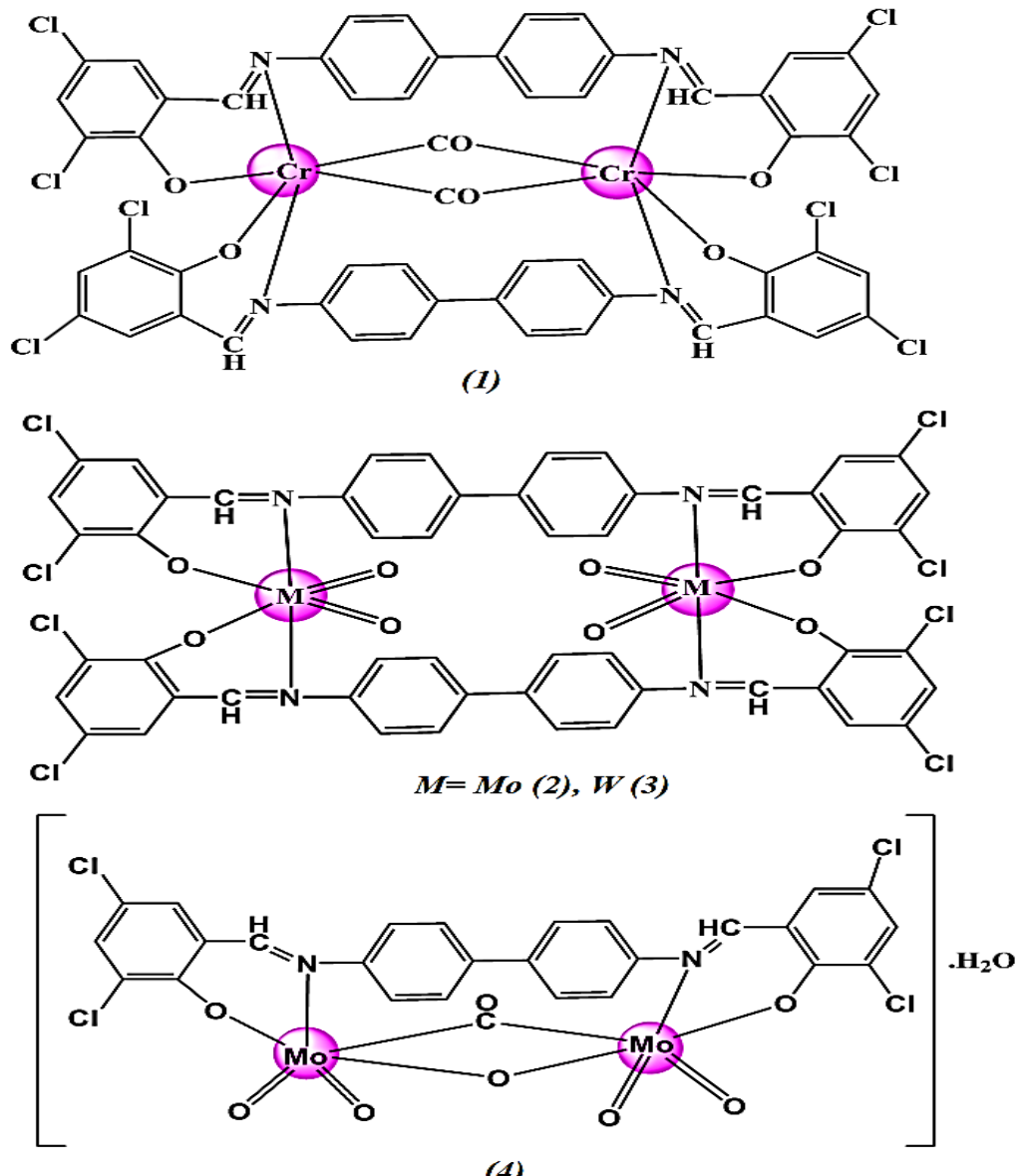

Fig.5. The structure of metal carbonyl complexes. 


\subsection{Electronic spectra}

Electronic absorption studies of Schiff base $\left(\mathrm{H}_{2} \mathrm{~L}\right)$ and its complexes were studied in DMSO (Table 4). The UV-Vis absorption spectrum of the $\mathrm{H}_{2} \mathrm{~L}$ ligand showed three absorption bands at $296 \mathrm{~nm}$ corresponding to $\pi-\pi^{*}$ and $386,454 \mathrm{~nm}$ corresponding to $n-\pi^{*}$ electronic transitions [36]. Hypsochromic shifts were carried out in the $\pi \rightarrow \pi^{*}$ and $n \rightarrow \pi^{*}$ electronic transitions in the spectra of 1 and 3 . In the spectra of complexes 2 and 4, a bathochromic shift in electronic transitions in the $\pi \rightarrow \pi^{*}$ was detected. while the $n \rightarrow \pi^{*}$ bands observed hypsochromic shift with a significant change in absorbance [37].

Table 4. The UV-Vis data of synthesized ligand and its complexes.

\begin{tabular}{|l|l|l|}
\hline \multirow{2}{*}{ Compound } & \multicolumn{2}{|c|}{ UV - Vis data } \\
& \multicolumn{2}{|c|}{$\lambda_{\max }(\mathrm{nm})$} \\
\cline { 2 - 3 } & $\pi \rightarrow \pi^{*}$ & $\mathrm{n} \rightarrow \pi^{*}$ \\
\hline $\mathrm{H}_{2} \mathrm{~L}$ & 296 & 386,454 \\
\hline 1 & 280 & 290 \\
\hline 2 & 294 & 366 \\
\hline 3 & 286 & 292 \\
\hline 4 & 294 & 320 \\
\hline
\end{tabular}

\subsection{Fluorescence spectra}

At room temperature, the photoluminescence examination of ligand and its complexes in DMSO was evaluated (Table 5 \& Fig. 6). Upon excitation at $386 \mathrm{~nm}$, the ligand showed maximum emission bands at 442 and $479 \mathrm{~nm}$. The emission bands of all complexes displayed a blue shift compared to that of the free ligand, in which, when excited at $292 \mathrm{~nm}$, both 2 and 3 showed maximum emission bands at 396 and $391 \mathrm{~nm}$. On the other hand, on excitation at $290 \mathrm{~nm}$, complex (1) exhibited an emission band at $352 \mathrm{~nm}$. The $\left[\mathrm{Mo}_{2} \mathrm{O}_{5}(\mathrm{CO}) \mathrm{L}\right] \cdot \mathrm{H}_{2} \mathrm{O}$ (4) complex showed no emission at $294 \mathrm{~nm}$ upon excitation. 
Table 5. The fluorescence data of the synthesized ligand and its complexes.

\begin{tabular}{|c|c|c|}
\hline \multirow[t]{2}{*}{ Compound } & \multicolumn{2}{|c|}{$\begin{array}{l}\text { Fluorescence data } \\
\qquad \lambda_{\max }(\mathrm{nm})\end{array}$} \\
\hline & Excitation & Emission \\
\hline $\mathrm{H}_{2} \mathrm{~L}$ & 386 & $410,442,479$ \\
\hline 1 & 290 & 362 \\
\hline 2 & 292 & 396 \\
\hline 3 & 292 & 391 \\
\hline 4 & 294 & - \\
\hline
\end{tabular}

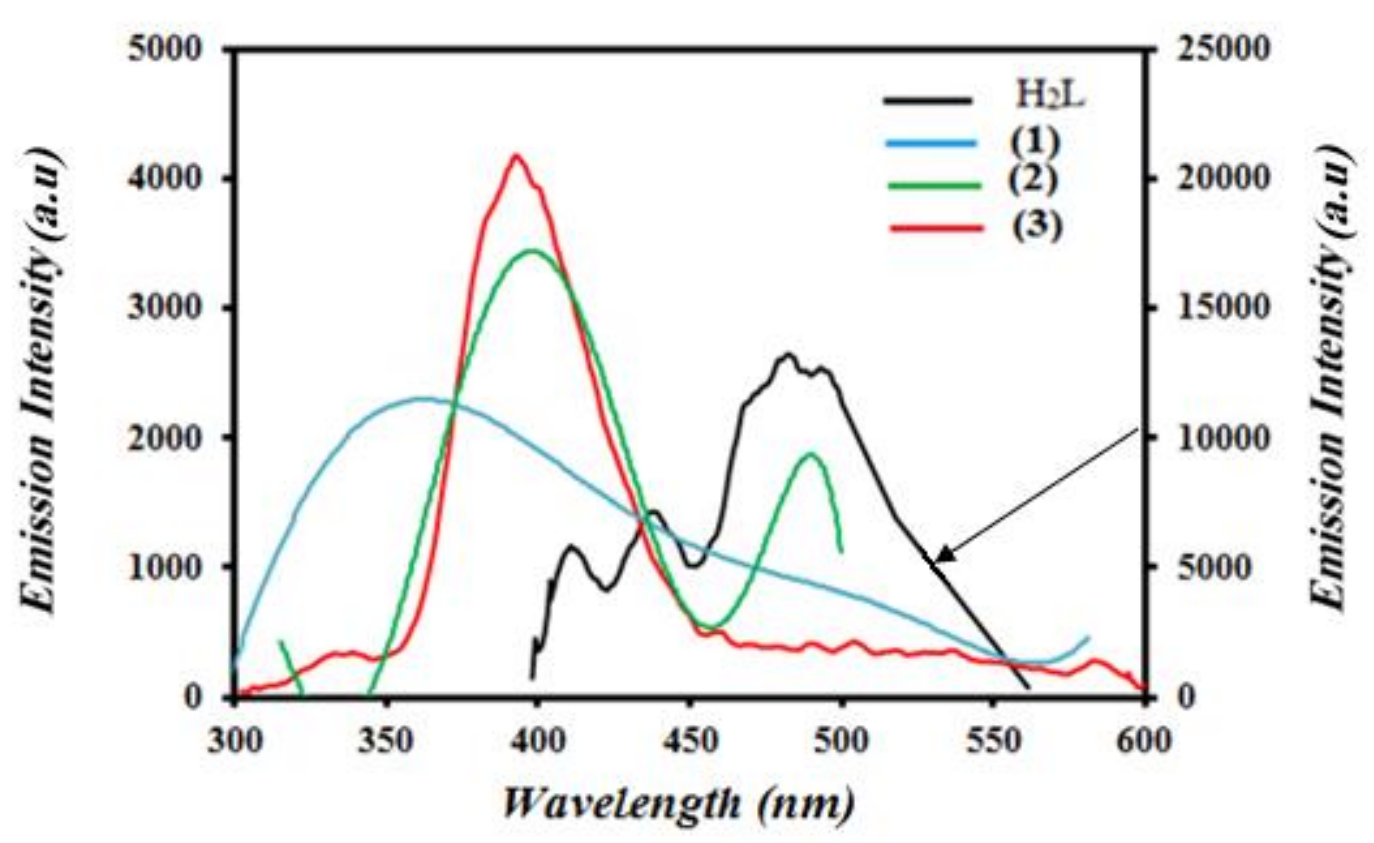

Fig.6. Fluorescence spectra of the ligand $\left(\mathrm{H}_{2} \mathrm{~L}\right)$ and its complexes.

\subsection{Thermal analysis}

The thermal decompositions of the $\left[\mathrm{Cr}_{2}(\mathrm{CO})_{2} \mathrm{~L}_{2}\right](1),\left[\mathrm{Mo}_{2} \mathrm{O}_{4}(\mathrm{~L})_{2}\right]$ (2), $\left[\mathrm{W}_{2} \mathrm{O}_{4}(\mathrm{~L})_{2}\right](3)$ and $\left[\mathrm{Mo}_{2} \mathrm{O}_{5}(\mathrm{CO}) \mathrm{L}\right] \cdot \mathrm{H}_{2} \mathrm{O}(4)$ complexes were performed within a 
temperature range from room temperature to $800{ }^{\circ} \mathrm{C}$ Fig. (7). The detailed thermal decomposition data for complexes gave in Table (6).

The complex (1) was decomposed thermally in three stages. The first decomposition step resulted at $95-264{ }^{\circ} \mathrm{C}$ with the elimination of $\left(2 \mathrm{CO}+4 \mathrm{Cl}_{2}\right)$ moieties. At $269-530{ }^{\circ} \mathrm{C}$, the second peak of decomposition occurred with a weight loss of 33.89 $\%$ (33.91\% calc.). The third decomposition stage occurred in the temperature range $540-800{ }^{\circ} \mathrm{C}$ with a net weight loss of $25.71 \%$ (25.68\% calc.) referred to the elimination of $\mathrm{C}_{24} \mathrm{H}_{8} \mathrm{O}$ species to give finally $\mathrm{Cr}_{2} \mathrm{O}_{3}$ as residue.

$$
\begin{aligned}
\mathrm{Cr}_{2} \mathrm{C}_{54} \mathrm{H}_{28} \mathrm{~N}_{4} \mathrm{O}_{6} \mathrm{Cl}_{8} & \stackrel{95-264{ }^{\circ} \mathrm{C}}{-\left(2 \mathrm{CO}+4 \mathrm{Cl}_{2}\right)} \mathrm{Cr}_{2} \mathrm{C}_{52} \mathrm{H}_{28} \mathrm{~N}_{4} \mathrm{O}_{4} \frac{269-530{ }^{\circ} \mathrm{C}}{-\left(\mathrm{C}_{28} \mathrm{H}_{20} \mathrm{~N}_{4}\right)} \mathrm{Cr}_{2} \mathrm{C}_{24} \mathrm{H}_{8} \mathrm{O}_{4} \\
& \stackrel{540-800}{\stackrel{5}{\circ} \mathrm{C}} \mathrm{Cr}_{2} \mathrm{O}_{3}
\end{aligned}
$$

The TGA curve of complex, 2 showed two thermal steps in the temperature range of $170-800{ }^{\circ} \mathrm{C}$. The first stage of decomposition at $170-561{ }^{\circ} \mathrm{C}$ with a net weight loss of $51.31 \%\left(51.05 \%\right.$ calc.) corresponded to the removal of $-\left(2 \mathrm{Cl}_{2}+\mathrm{L}\right)$ species. The second step of decomposition resulted in a weight loss of $23.24 \%$ (23.35\% calc.) due to the elimination of $\mathrm{C}_{22} \mathrm{H}_{12} \mathrm{~N}_{2}$ species, leaving finally a residue of $2 \mathrm{MoO}_{3}+4 \mathrm{C}$ with a net weight of 25.45 percent (25.60 percent calc.).

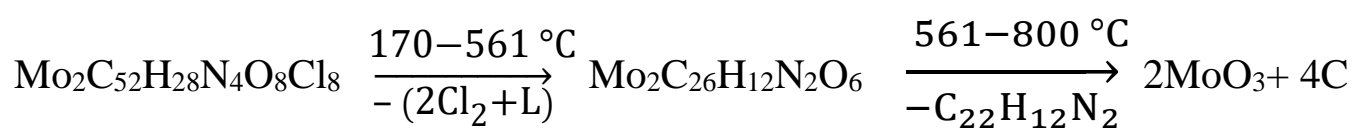

The TGA plot of complex, 3 showed two resolved well-defined decomposition steps within temperature range $150-798^{\circ} \mathrm{C}$. The first decomposition step occurred in the temperature range $150-489^{\circ} \mathrm{C}$ with a net weight loss of $35.13 \%$ (35.49\% calc.) which corresponds to the loss of $2 \mathrm{Cl}_{2}+\mathrm{L}$ species. The second decomposition stage occurred in the temperature range $490-798{ }^{\circ} \mathrm{C}$ with a weight loss of $36.45 \%(36.57 \%$ calc.) to give finally a solid residue $\mathrm{W}_{2} \mathrm{O}_{3}$ with a net weight of $28.42 \%$ (27.93\% calc.).

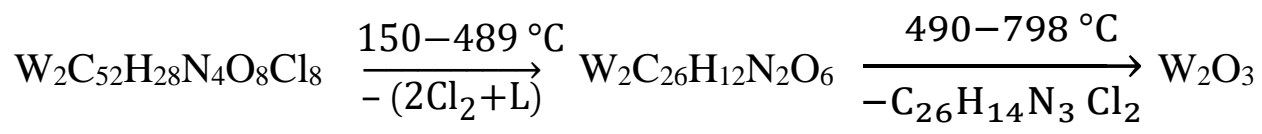

The complex (4) decomposed in three stages within the temperature ranges 25 $800{ }^{\circ} \mathrm{C}$. The first step occurred in the range $25-262^{\circ} \mathrm{C}$ of temperature with a net loss of 
weight $($ Found $=13.78 \%$, Calc. $=13.82 \%)$, which corresponds to the loss of $\left(\mathrm{CO}+\mathrm{H}_{2} \mathrm{O}+\mathrm{Cl}_{2}\right)$ species. The second and third decomposition steps occurred in the temperature range $265-572{ }^{\circ} \mathrm{C}$ and $610-800{ }^{\circ} \mathrm{C}$, respectively, to give finally a residue $2 \mathrm{MoO}_{3}$.

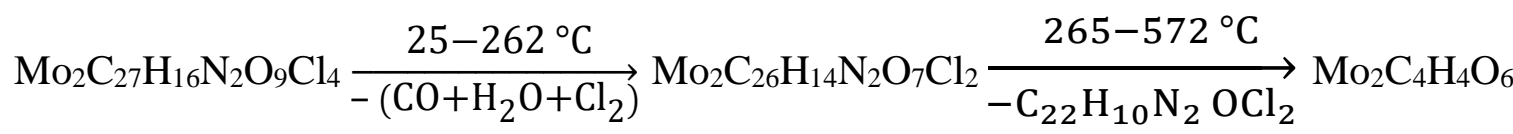
$\underset{-\mathrm{C}_{4} \mathrm{H}_{4}}{\stackrel{610-800}{\longrightarrow}} \stackrel{\circ}{\circ} 2 \mathrm{MoO}_{3}$

Table 6. Thermogravimetric data of Schiff base metal complexes.

\begin{tabular}{|c|c|c|c|c|c|c|}
\hline \multirow[t]{2}{*}{ Compound } & \multirow[t]{2}{*}{ Stage } & \multirow{2}{*}{$\begin{array}{l}\text { Temp. } \\
{ }^{\circ} \mathrm{C}\end{array}$} & \multicolumn{2}{|c|}{ Mass loss (\%) } & \multirow{2}{*}{$\begin{array}{l}\text { Evolved } \\
\text { moiety }\end{array}$} & \multirow{2}{*}{$\begin{array}{l}\text { Residue (\%) } \\
\text { Found (Calc.) }\end{array}$} \\
\hline & & & found & (Calc.) & & \\
\hline \multirow[t]{3}{*}{ (1) } & I & $95-264$ & 27.95 & 27.92 & $2 \mathrm{CO}+4 \mathrm{Cl}_{2}$ & $\mathrm{Cr}_{2} \mathrm{O}_{3}$ \\
\hline & II & $269-530$ & 33.89 & 33.91 & $\mathrm{C}_{28} \mathrm{H}_{20} \mathrm{~N}_{4}$ & $12.45(12.49)$ \\
\hline & III & $540-800$ & 25.71 & 25.68 & $\mathrm{C}_{24} \mathrm{H}_{8} \mathrm{O}$ & \\
\hline \multirow[t]{2}{*}{ (2) } & I & $170-561$ & 51.31 & 51.05 & $2 \mathrm{Cl}_{2}+\mathrm{L}$ & $2 \mathrm{MoO}_{3}+4 \mathrm{C}$ \\
\hline & II & $561-800$ & 23.24 & 23.35 & $\mathrm{C}_{22} \mathrm{H}_{12} \mathrm{~N}_{2}$ & $25.45(25.60)$ \\
\hline \multirow[t]{2}{*}{ (3) } & I & $150-489$ & 35.13 & 35.49 & $2 \mathrm{Cl}_{2}+\mathrm{L}$ & $\mathrm{W}_{2} \mathrm{O}_{3}$ \\
\hline & II & $490-798$ & 36.45 & 36.57 & $\mathrm{C}_{26} \mathrm{H}_{14} \mathrm{~N}_{2} \mathrm{O}_{3} \mathrm{Cl}_{2}$ & $28.42(27.93)$ \\
\hline \multirow{3}{*}{ (4) } & I & $25-262$ & 13.78 & 13.82 & $\mathrm{CO}+\mathrm{H}_{2} \mathrm{O}+\mathrm{Cl}_{2}$ & $2 \mathrm{MoO}_{3}$ \\
\hline & II & $265-572$ & 46.02 & 46.00 & $\mathrm{C}_{22} \mathrm{H}_{10} \mathrm{~N}_{2} \mathrm{OCl}_{2}$ & $34.04(34.03)$ \\
\hline & III & $610-800$ & 6.16 & 6.15 & $\mathrm{C}_{4} \mathrm{H}_{4}$ & \\
\hline
\end{tabular}




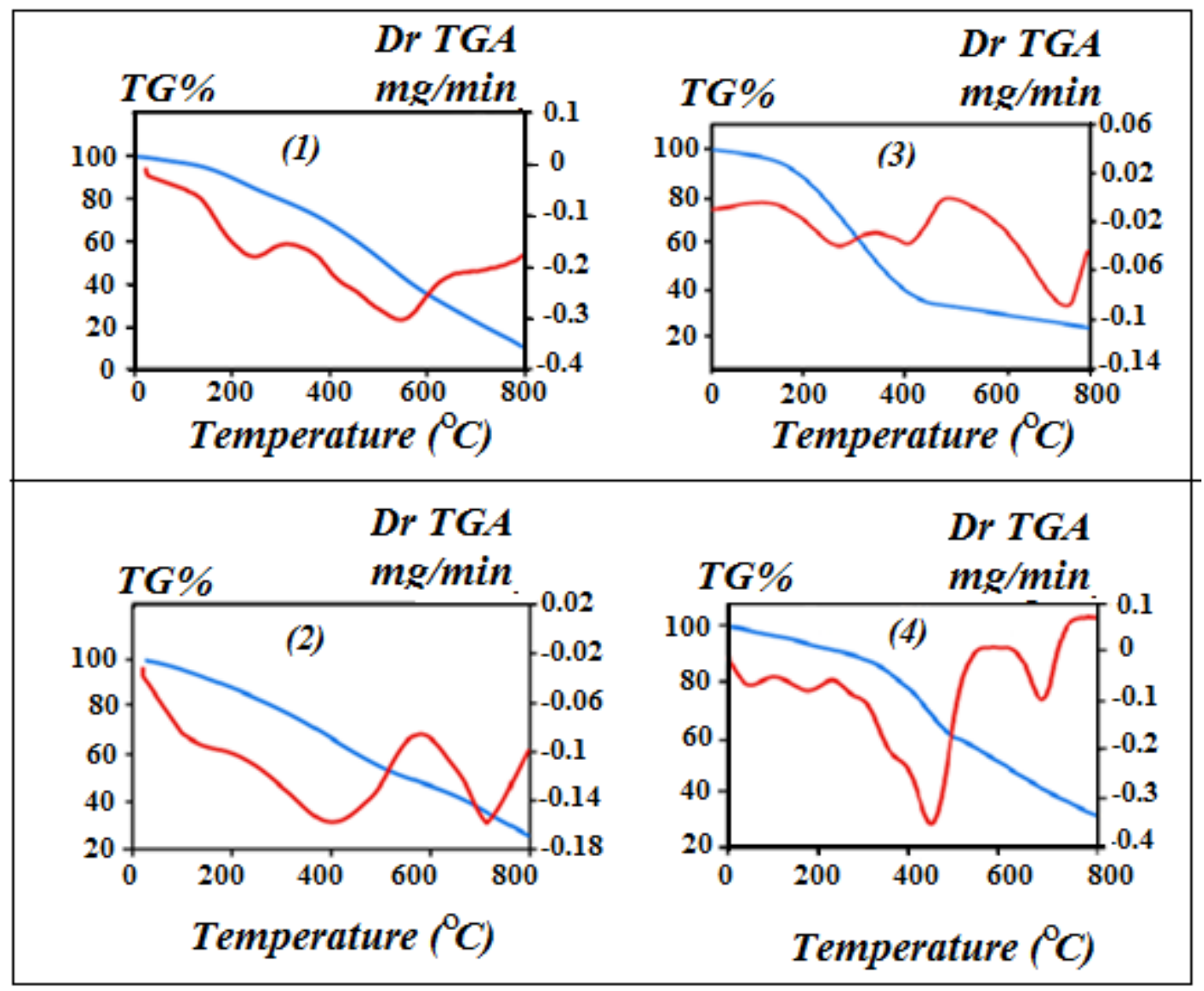

Fig.7. TG-DT thermograms of metal carbonyl complexes.

\subsubsection{Kinetic data}

The kinetic analysis parameters such as activation energy $\left(\mathrm{E}^{*}\right)$, enthalpy of activation $\left(\Delta \mathrm{H}^{*}\right)$, the entropy of activation $\left(\Delta \mathrm{S}^{*}\right)$ and Gibbs free energy change of decomposition $\left(\Delta \mathrm{G}^{*}\right)$ for the thermal degradation of all complexes have been tested using Coats-Redfern (CR) [38] and Horowitz-Metzger (HM) [39] relationships (Figs 8-9). The data are summarized in Table (8). The entropy of activation was found to have negative values for all metal complexes which denoting that decomposition reactions proceed with a lower rate than normal ones [40-41]. The activation energies of decomposition were found to be in the range of 3.53-74.32 $\mathrm{kJ} \mathrm{mol}^{-1}$. The high values of the activation energies reflect the thermal stability of the complexes [42]. 
Table 7: Kinetic thermodynamic data of Schiff base metal complexes.

\begin{tabular}{|c|c|c|c|c|c|c|c|c|c|c|}
\hline Compound & Stage & $\begin{array}{l}\text { Ts } \\
{ }^{\circ} \mathrm{C}\end{array}$ & $\begin{array}{l}\text { Decomposition } \\
\text { range. }{ }^{\circ} \mathrm{C}\end{array}$ & Method & $\mathbf{A}\left(\mathbf{S}^{-1}\right)$ & $\begin{array}{l}\Delta \mathbf{H}^{\#} \\
(\mathbf{K J} / \mathbf{m o l})\end{array}$ & $\begin{array}{c}\Delta \mathbf{S}^{\#} \\
(\mathbf{K J} / \mathbf{m o l})\end{array}$ & $\begin{array}{l}\Delta \mathbf{G}^{\#} \\
(\mathbf{K J} / \mathbf{m o l})\end{array}$ & $\begin{array}{c}\text { Ea } \\
(\mathrm{KJ} / \mathbf{m o l})\end{array}$ & $\mathbf{R}^{2}$ \\
\hline \multirow[t]{3}{*}{1} & I & 211 & $95-264$ & $\begin{array}{l}\mathrm{CR} \\
\mathrm{HM}\end{array}$ & $\begin{array}{l}8.4 \times 10^{-4} \\
7.48\end{array}$ & $\begin{array}{l}17.13 \\
38.03\end{array}$ & $\begin{array}{l}-243.52 \\
-174.81\end{array}$ & $\begin{array}{l}68.51 \\
122.64\end{array}$ & $\begin{array}{l}18.89 \\
42.06\end{array}$ & $\begin{array}{l}0.991 \\
0.958\end{array}$ \\
\hline & II & 464 & $269-530$ & $\begin{array}{l}\mathrm{CR} \\
\mathrm{HM}\end{array}$ & $\begin{array}{l}2 \times 10^{-4} \\
2.3 \times 10^{-3}\end{array}$ & $\begin{array}{l}27.35 \\
9.41\end{array}$ & $\begin{array}{l}-262.03 \\
-241.66\end{array}$ & $\begin{array}{r}195.89 \\
121.54\end{array}$ & $\begin{array}{l}18.30 \\
13.27\end{array}$ & $\begin{array}{l}0.955 \\
0.999\end{array}$ \\
\hline & III & 664 & $540-730$ & $\begin{array}{l}\mathrm{CR} \\
\mathrm{HM}\end{array}$ & $\begin{array}{l}8.4 \times 10^{-4} \\
1.3 \times 10^{-3}\end{array}$ & $\begin{array}{l}13.36 \\
12.63\end{array}$ & $\begin{array}{l}-253.05 \\
-249.25\end{array}$ & $\begin{array}{l}181.39 \\
178.14\end{array}$ & $\begin{array}{l}18.89 \\
18.15\end{array}$ & $\begin{array}{l}0.988 \\
0.999\end{array}$ \\
\hline \multirow[t]{2}{*}{2} & I & 379 & $170-561$ & $\begin{array}{l}\mathrm{CR} \\
\mathrm{HM}\end{array}$ & $\begin{array}{l}1.2 \times 10^{-6} \\
2.5 \times 10^{-3}\end{array}$ & $\begin{array}{l}0.62 \\
6.91\end{array}$ & $\begin{array}{l}-302.71 \\
-240.96\end{array}$ & $\begin{array}{l}114.11 \\
98.23\end{array}$ & $\begin{array}{l}2.532 \\
10.063\end{array}$ & $\begin{array}{l}0.996 \\
0.985\end{array}$ \\
\hline & II & 715 & $560-795$ & $\begin{array}{l}\mathrm{CR} \\
\mathrm{HM}\end{array}$ & $\begin{array}{l}1.2 \times 10^{-6} \\
1.6 \times 10^{-3}\end{array}$ & $\begin{array}{l}2.89 \\
14.92\end{array}$ & $\begin{array}{l}-307.22 \\
-248.09\end{array}$ & $\begin{array}{l}197.41 \\
192.31\end{array}$ & $\begin{array}{l}2.53 \\
20.87\end{array}$ & $\begin{array}{l}0.994 \\
0.999\end{array}$ \\
\hline \multirow[t]{3}{*}{3} & I & 450 & $308-493$ & $\begin{array}{l}\mathrm{CR} \\
\mathrm{HM}\end{array}$ & $\begin{array}{l}4 \times 10^{-6} \\
2.4 \times 10^{-2}\end{array}$ & $\begin{array}{l}51.78 \\
28.37\end{array}$ & $\begin{array}{l}-298.23 \\
-225.84\end{array}$ & $\begin{array}{l}220.81 \\
191.66\end{array}$ & $\begin{array}{l}11.20 \\
28.37\end{array}$ & $\begin{array}{l}0.976 \\
0.972\end{array}$ \\
\hline & II & 540 & 494-660 & $\begin{array}{l}\mathrm{CR} \\
\mathrm{HM}\end{array}$ & $\begin{array}{l}1.2 \times 10^{-5} \\
3.4 \times 10^{-3}\end{array}$ & $\begin{array}{l}78.71 \\
20.94\end{array}$ & $\begin{array}{l}-291.39 \\
-244.05\end{array}$ & $\begin{array}{l}244.77 \\
219.36\end{array}$ & $\begin{array}{l}14.63 \\
27.71\end{array}$ & $\begin{array}{l}0.987 \\
0.994\end{array}$ \\
\hline & III & 560 & $662-798$ & $\begin{array}{l}\mathrm{CR} \\
\mathrm{HM}\end{array}$ & $\begin{array}{l}2.3 \times 10^{-5} \\
1.3 \times 10^{-3}\end{array}$ & $\begin{array}{l}14.91 \\
16.82\end{array}$ & $\begin{array}{l}-282.86 \\
-251.51\end{array}$ & $\begin{array}{l}250.52 \\
226.33\end{array}$ & $\begin{array}{l}21.83 \\
23.75\end{array}$ & $\begin{array}{l}0.972 \\
0.985\end{array}$ \\
\hline \multirow[t]{3}{*}{4} & I & 117 & $25-262$ & $\begin{array}{l}\mathrm{CR} \\
\mathrm{HM}\end{array}$ & $\begin{array}{l}1.5 \times 10^{-5} \\
2.1 \times 10^{-3}\end{array}$ & $\begin{array}{l}4.97 \\
6.91\end{array}$ & $\begin{array}{l}-281.63 \\
-240.96\end{array}$ & $\begin{array}{l}111.71 \\
98.23\end{array}$ & $\begin{array}{l}8.123 \\
10.06\end{array}$ & $\begin{array}{l}0.962 \\
0.968\end{array}$ \\
\hline & II & 455 & $265-572$ & $\begin{array}{l}\mathrm{CR} \\
\mathrm{HM}\end{array}$ & $\begin{array}{l}4.5 \times 10^{-6} \\
8.4 \times 10^{-3}\end{array}$ & $\begin{array}{l}23.275 \\
8.09\end{array}$ & $\begin{array}{l}-67.46 \\
-234.61\end{array}$ & $\begin{array}{l}57.21 \\
194.07\end{array}$ & $\begin{array}{l}14.15 \\
29.32\end{array}$ & $\begin{array}{l}0.972 \\
0.993\end{array}$ \\
\hline & III & 757 & $720-798$ & $\begin{array}{l}\mathrm{CR} \\
\mathrm{HM}\end{array}$ & $\begin{array}{l}1.2 \times 10^{-6} \\
0.5 \times 10^{-2}\end{array}$ & $\begin{array}{l}0.31 \\
65.76\end{array}$ & $\begin{array}{l}-311.33 \\
-203.65\end{array}$ & $\begin{array}{l}320.98 \\
275.53\end{array}$ & $\begin{array}{l}8.87 \\
74.32\end{array}$ & $\begin{array}{l}0.981 \\
0.971\end{array}$ \\
\hline
\end{tabular}




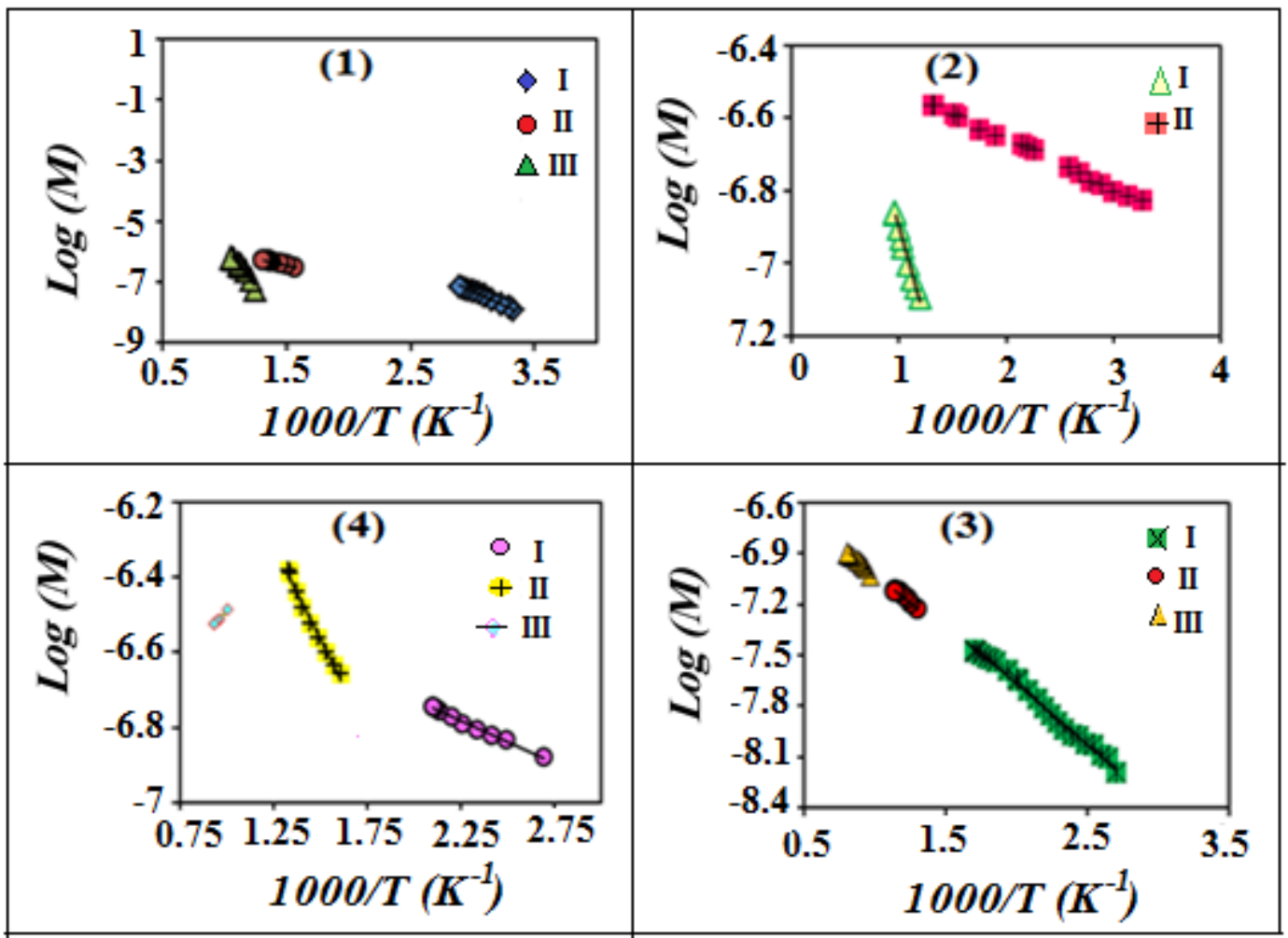

Fig. 8. Coats-Redfern plots of complexes. $\log M=\log \left[\log \left\{\mathrm{W}_{\infty}\left(\mathrm{W}_{\infty}-\mathrm{W}\right)^{-1}\right\} \mathrm{T}^{-2}\right]$.

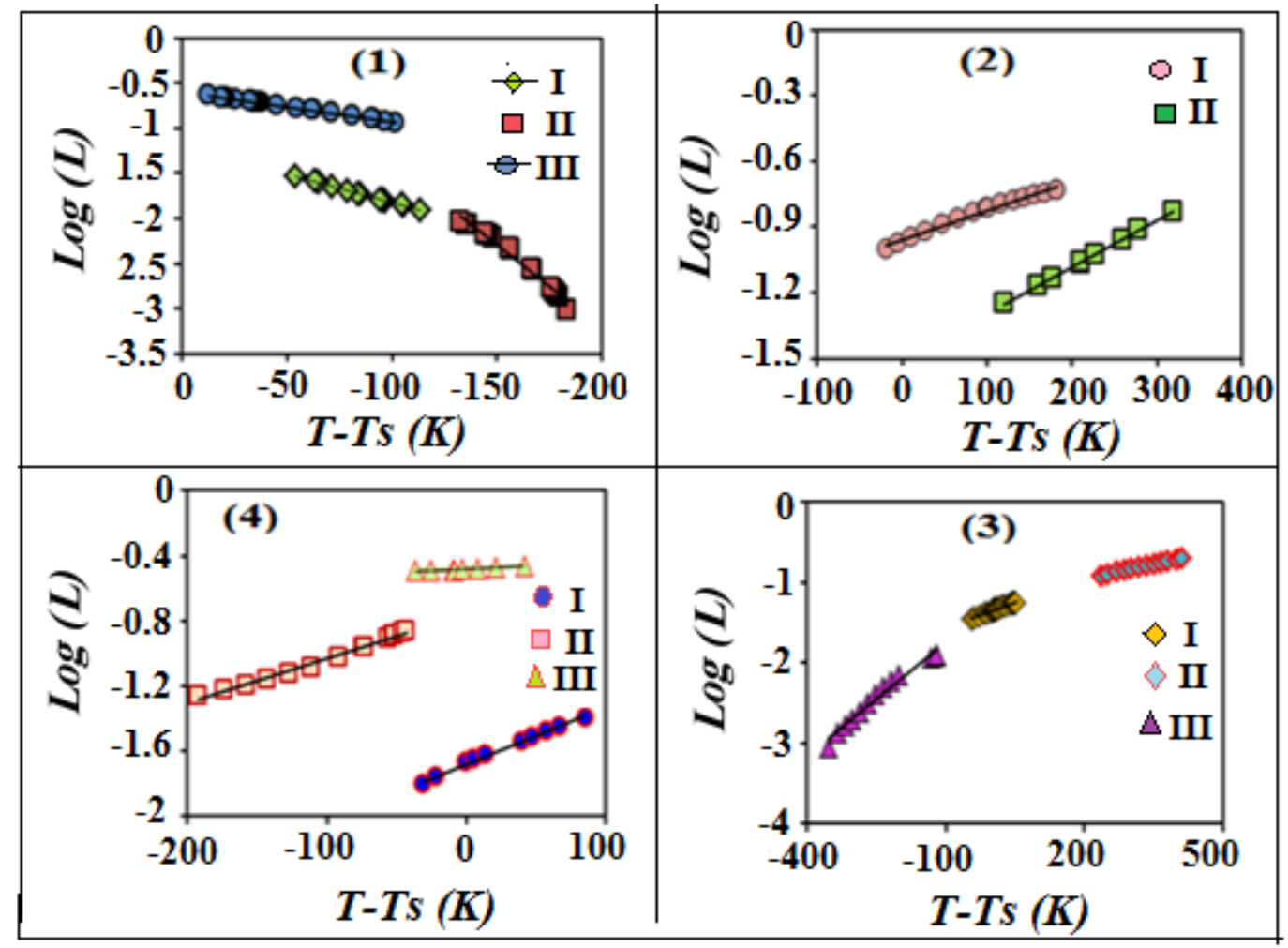

Fig.9. Horowitz-Metzger plots of complexes. $\log \mathrm{L}=\log \left[\log \left\{\mathrm{W}_{\infty}\left(\mathrm{W}_{\infty}-\mathrm{W}\right)^{-1}\right\}\right]$. 


\subsection{Optical properties}

From the electronic spectra of the complexes, the optical band gap $\left(\mathrm{E}_{\mathrm{g}}\right)$ was estimated using the relationship below:

$\alpha h v=A\left(h v-E_{g}\right)^{m}$, where $m$ is equal to $1 / 2$ and 2 for indirect and direct transition respectively, $\mathrm{A}$ is energy independent constant and from the relation $\alpha=1 / \mathrm{d} \ln \mathrm{A}$ (where $A$ is the absorbance and $d$ is the width of the cell), $\alpha$ was determined [43]. The plot $(\alpha h v)^{2}$ vs. ho indicated that the type of electronic transition was direct (Fig.10). The values of band gap (Eg) equal to 3.51, 2.91, 3.52 and $3.49 \mathrm{eV}$ for complexes (1), (2), (3) and (4), respectively. This reveals that these complexes could be used as promising materials for optoelectronic devices [44].

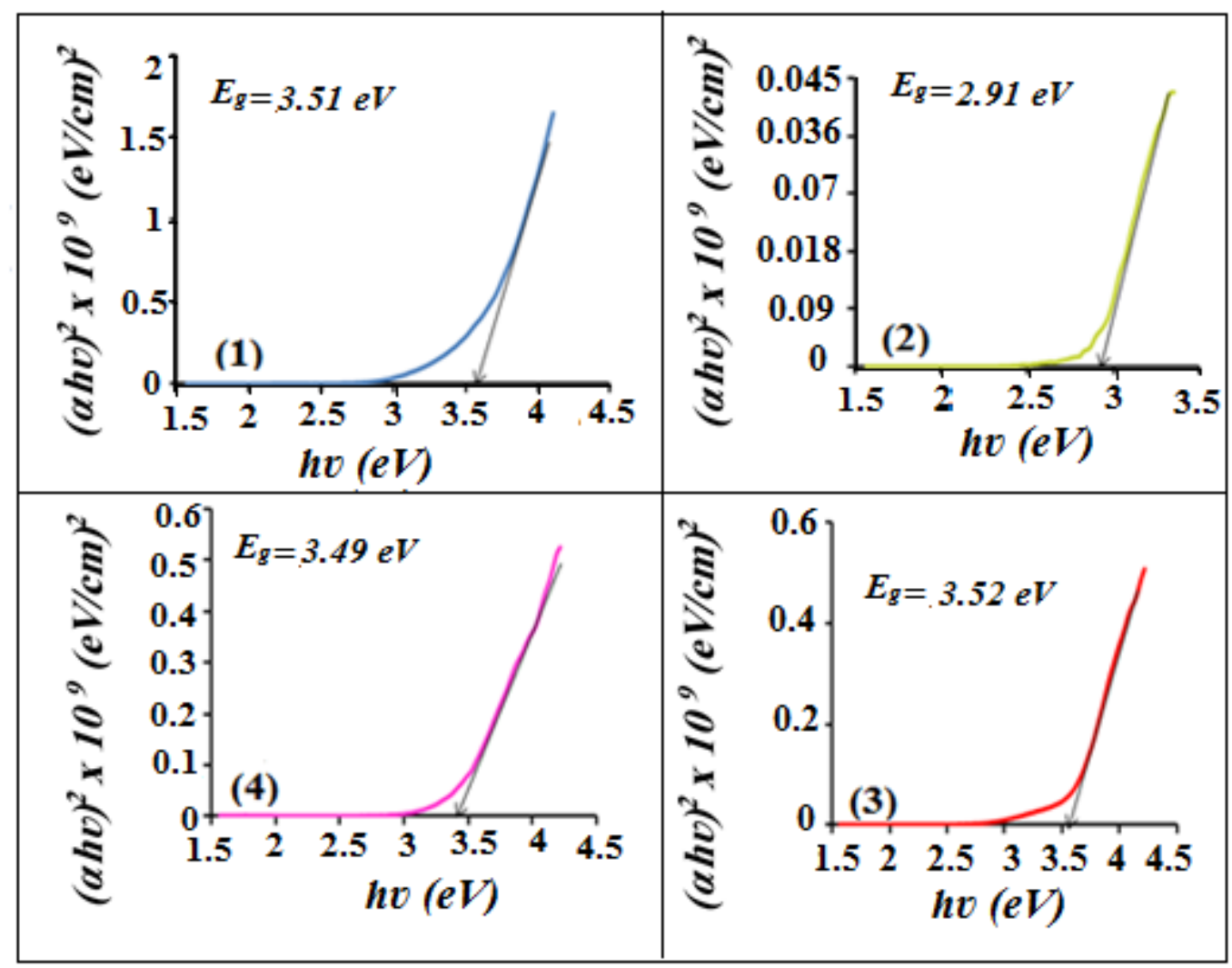

Fig.10. The optical band gap of complexes. 


\section{Conclusion}

Four new complexes were synthesized from the reactions of $\mathrm{M}(\mathrm{CO})_{6}(\mathrm{M}=\mathrm{Cr}$, Mo, W) with the 6,6'(([1,1'biphenyl]4,4'diylbis(azaneylylidene)) bis(methaneylylidene))bis(2,4dichlorophenol) $\left(\mathrm{H}_{2} \mathrm{~L}\right)$ Schiff base in THF. The binuclear carbonyl complex $\left[\mathrm{Cr}_{2}(\mathrm{CO})_{2}(\mathrm{~L})_{2}\right]$ and three oxo complexes $\left[\mathrm{Mo}_{2} \mathrm{O}_{4}(\mathrm{~L})_{2}\right], \quad\left[\mathrm{W}_{2} \mathrm{O}_{4}(\mathrm{~L})_{2}\right]$ and $\left[\mathrm{Mo}_{2} \mathrm{O}_{5}(\mathrm{CO}) \mathrm{L}\right] \cdot \mathrm{H}_{2} \mathrm{O}$ were characterized. Analytical and spectral data showed that $\mathrm{H}_{2} \mathrm{~L}$ was co-ordinated as a dibasic ligand via two imine nitrogen and two deprotonated phenolic oxygen atoms. The magnetic measurements of the synthesized complexes showed all the complexes were diamagnetic except $\left[\mathrm{Cr}_{2}(\mathrm{CO})_{2}(\mathrm{~L})_{2}\right]$ complex was paramagnetic. Activation thermodynamic parameters, such as activation energy, enthalpy, entropy and Gibbs free energy change of complex decomposition, have been determined from the TG curves. Furthermore, these complexes exhibited fluorescence properties and could be used as photoactive materials. The optical band gap values of all complexes illustrate the semi-conductivity properties of these compounds.

\section{References}

[1] X. F. Luo, X. Hu, X. Y. Zhao, S. H. Goh, X. D. Li, Miscibility and interactions in blends and complexes of poly(4-methyl-5-vinylthiazole) with proton-donating polymers, Polymer, 44: (2003) 5285-5291.

[2] R. Baumgrass, M. Weiwad, F. Erdmann, J. O. Liu, D. Wunderlich, S. Grabley, G. Fischer, Reversible inhibition of calcineurin by the polyphenolic aldehyde gossypol, J Bio Chem., 276:(2001) 47914-47921.

[3] C. A. Hunter, Self-Assembly of Molecular-Sized Boxes, Angew Chem Int Ed Engl., 34:(1995) 1079-1081.

[4] P. J. Stang, D. H. Cao, S. Saito, A. M. Arif, Self-Assembly of Cationic, Tetranuclear, Pt (II) and Pd (II) Macrocyclic Squares. X-ray Crystal Structure of $\left[\mathrm{Pt}^{2+} \text { (dppp)(4, 4'-bipyridyl). cntdot. 2-OSO } \mathrm{CF}_{3}\right]_{4}$, J Am Chem Soc., 117: (1995) 6273-6283.

[5] I. Y. Wu, J. T. Lin, J. Luo, S. S. Sun, C. S. Li, K. J. Lin, C. Tsai, C. C. Hsu, J. L. Lin, Syntheses and Reactivity of Ruthenium $\sigma$-Pyridylacetylides, Organomettalics, 16: (1997) 2038-2048.

[6] A. A. Abu-Hussen, Synthesis and spectroscopic studies on ternary bis-Schiff-base complexes having oxygen and/or nitrogen donors, J Coord Chem., 59: (2006) 157176.

[7] M. S. Karthikeyan, D. J. Parsad, B. Poojary, K. S. Bhat, B. S. Holla, N. S. Kumari, Synthesis and biological activity of Schiff and Mannich bases bearing 2, 4dichloro-5-fluorophenyl moiety, Bioorg Med Chem., 14: (2006) 7482-7489. 
[8] S. M. El-Medani, Structural studies of some chromium, molybdenum and tungsten complexes of N-salicylidene-2- hydroxyaniline, J Coord Chem., 57: (2004) 115122.

[9] S. M. El-Medani, Reactions of chromium, molybdenum and tungsten carbonyls with a tetradentate Schiff base, J Coord Chem., 57: (2004) 497-507.

[10] S. M. El-Medani, M. M. Aboaly, H. H. Abdalla, R. M. Ramadan, Reactions of group 6 metal carbonyls with salicylaldehyde hydrazone, Spectroscopy Lett., 37: (2004) 619-632.

[11] J. Collman L. S. Hegedus, Principles and Application of Organotransition Metal Chemistry, University Science Book, CA, 1980.

[12] J. Zhao, B. Zhao, J. Liu, W. Xu, Z. Wang, Spectroscopy study on the photochromism of Schiff Bases $N, N^{\prime}$-bis(salicylidene)-1,2-diaminoethane and $N, N^{\prime}$-bis(salicylidene)-1,6 hexanediamine, Spectrochim Acta A., 57: (2001) 149-154.

[13] S. A. Ali, A. A. Soliman, M. M. Aboaly, R. M. Ramdan, chromium, molybdenum and ruthenium complexes of 2-Hydroxyacetophenone Schiff bases, J Coord Chem., 55: (2002) 1161-1170.

[14] A. A. Soliman, S. M. El-Medani, O. A. M. Ali, Thermal study of chromium and molybdenum complexes with some nitrogen and nitrogen-oxygen donors ligands, J Ther Analy and Calor., 83: (2006) 385-392.

[15] S. M. El-Medani, , O. A. M. Ali, R. M. Ramadan, Photochemical reactions of group 6 metal carbonyls with N-salicylidene-2-hydroxyaniline and bis (salicylaldehyde)phenylenediimine, J Mol Struct., 738: (2005) 171-177.

[16] C. Silva da, D. Silva da, L. Modolo, R. Alves, Schiff bases: A short review of their antimicrobial activities, J Ad Res., 2: (2011) 1-8.

[17] X. Yang, Q. Wang, Y. Huang, P. Fu, J. Zhang, R. Zeng, Synthesis, DNA interaction and antimicrobial activities of copper (II) complexes with Schiff base ligands derived from kaempferol and polyamines, Inorg Chem Com., 25: (2012) $55-59$.

[18] S. Kumar, D. N. Dhar, P. N. Saxena, Applications of metal complexes of Schiff bases - a review, J Sci Ind Res., 68: (2009) 181-187.

[19] T. H. Sanatkar, A. Khorshidi, E. Sohouli, and J. Janczak, Synthesis, Crystal Structure, and Characterization of Two $\mathrm{Cu}$ (II) and $\mathrm{Ni}(\mathrm{II})$ Complexes of a Tetradentate $\mathrm{N}_{2} \mathrm{O}_{2}$ Schiff Base Ligand and Their Application in Fabrication of a Hydrazine Electrochemical Sensor, Inorg Chim Acta., 506: (2020) 119537119548.

[20] S. E. Abd El-Razek, S. M. El-Gamasy, M. Hassan, M. S. Abdel-Aziz, S. M. Nasr, Transition Metal Complexes of a Multidentate Schiff Base Ligand Containing Guanidine Moiety: Synthesis, Characterization, Anti-Cancer Effect, and AntiMicrobial Activity, J Mol Struct., 1203: (2020) 127381-127390.

[21] O. A. M. Ali, M. M. H. Khalil, G. M. Attia, R. M. Ramadan, Group VI Dinuclear Oxo Metal Complexes of Salicylideneimine-2-Anisole Schiff Base, Spectroscopy Lett., 36: (2003) 71-82. 
[22] R. G. Mohamed, F. M. Elantabli, N. H. Helal, S. M. El-Medani, New Group 6 Metal Carbonyl Complexes with 4,5-Dimethyl-N,N-Bis(Pyridine-2YlMethylene)Benzene-1,2-Diimine Schiff Base: Synthesis, Spectral, Cyclic Voltammetry and Biological Activity Studies, Spectrochim Acta A Mol Biomol Spectrosc., 141: (2015) 316-326.

[23] Y. Guo, X. Hu, X. Zhang, X. Pu, Y. Wang, The Synthesis of a Cu(Ii) Schiff Base Complex Using a Bidentate $\mathrm{N}_{2} \mathrm{O}_{2}$ Donor Ligand: Crystal Structure, Photophysical Properties, and Antibacterial Activities, RSC Adv., 9: (2019) 41737-41744.

[24] A. A. Soliman, S. A. Ali, A. H. Marei, D. H. Nassar, Synthesis, characterization and biological activities of some new chromium, molybdenum and tungsten complexes with 2,6-diaminopyridine, Spectrochim Acta A., 89: (2012) 329-332.

[25] M. M. H. Khalil, H. A. Mohamed, S. M. El-Medani R. M. Ramadan, New group 6 metal carbonyl derivatives of 2-(2-pyridyl) benzimidazole: synthesis and spectroscopic studies, Spectrochim Acta A., 59: (2003) 1341-1347.

[26] M. A. Taher, S. E. Jarelnabbi, B. E. Bayoumy, S. M. El-Medani, R. M. Ramadan, "Synthesis and Spectroscopic Studies of Some New Molybdenum, Tungsten, and Ruthenium Carbonyl Derivatives of 2-Hydroxymethylpyridine, Inter J Inorg Chem., 2010: (2010) 1-6.

[27] A. B. Garin, D. Rakarić, E. K. Andrić, M. M. Kosanović, T. Balić, F. Perdih, Synthesis of Monosubstituted Dipicolinic Acid Hydrazide Derivative and Structural Characterization of Novel $\mathrm{Co}(\mathrm{III})$ and $\mathrm{Cr}$ (III) Complexes, Polyhedron.,166: (2019) 226-232.

[28] O. A. M. Ali, S. M. El-Medani, D. A. Ahmed, D. A. Nassar, Metal carbonyl complexes with Schiff bases derived from 2-pyridinecarboxaldehyde: Syntheses, spectral, catalytic activity and antimicrobial activity studies, J Mol Struct., 1074: (2014) 713-722.

[29] S. A. Ali, A. A. Soliman, A. H. Marei, D. H. Nassar, Synthesis and characterization of new chromium, molybdenum and tungsten complexes of 2-[2(methylaminoethyl)] pyridine, Spectrochim Acta A., 94: (2012) 164-168.

[30] P. Datta, D. Sardar, A. P. Mukhopadhyay, E. López-Torres, C. J. Pastor, C. Sinha, Group-6 Metal Carbonyl Complexes of Pyridylbenzoxazole and Pyridylbenzothiazole: Synthesis", Structure, Electrochemistry, Photophysical Property and DFT Calculations, J Organomet Chem., 696: (2011) 488-495.

[31] M. M. H. Khalil F. A. Al-Seif, Group 6 Metal Carbonyl Complexes of 3'HSpiro[Indole-3,2'-[1,3]Benzothiazole-2(1H)]-One, J Saudi Chem Soc., 14: (2010) 33-39.

[32] S. M. Abdallah, M. A. Zayed, G. G. Mohamed, Synthesis and Spectroscopic Studies of New tetradentate Schiff base and its coordition compounds of NOON donor atoms and their antibactrial and antifungal activity, Arabian J Chem., 3: (2010) 103-113.

[33] L. H. Abdel-Rahman, A. M. Abu-Dief, R. M. El-Khatib, S. M. Abdel-Fatah, Some New Nano-Sized Fe(II), Cd(II) and Zn(II) Schiff Base Complexes as Precursor for 
Metal Oxides: Sonochemical Synthesis, Characterization, DNA Interaction, in Vitro Antimicrobial and Anticancer Activities, Bioorg Chem., 69: (2016) 140-152.

[34] H. A. Mohamed, Photochemical reactions of chromium, molybdenum and tungsten hexacarbonyls with dimethylglyoxime, J Mol Struct., 784: (2006) 254258.

[35] O. A. M. Ali, Synthesis and characterization of molybdenum complexes with salicylideneimine-2-anisole and certain heterocyclic nitrogen ligands, J Coord Chem. 60: (2007) 1213-1221.

[36] Y. Salman, F. B. Barlas, M. Yavuz, K. Kaya, S. Timur, F. Ç. Telli, Synthesis, characterization and biological application of dinuclear $\mathrm{Cu}$ (II) complexes of Schiff base ligands of galactochloralose and $\alpha$-chloralose, Inorg Chim Acta., 483: (2018) 98-105.

[37] O. A. M. Ali, A. K. Abu Al-Nasr, R. M. Ramadan, "Synthesis and spectroscopic and structural studies of ruthenium carbonyl derivatives of $\mathrm{N}$-salicylidene-2 hydroxyaniline Schiff base, J Taibah Uni Sci., 8: (2014) 258-264.

[38] A. W. Coats J. P. Redfern, Kinetic Parameters from Thermogravimetric Data, Nature. 201: (1964) 68-69.

[39] H. W. Horowitz, G. A. Metzger, A New Analysis of Thermogravimetric Traces, Analy Chem., 35: (1963) 1464-1468.

[40] A. A. Frost, R. G. Pearson, Kinetics and Mechanism - A Study of Homogeneous Chemical Reactions, John Wiley, New York., 73: (1961) 719-719.

[41]. W. H. Mahmoud, G. G. Mohamed, M. M. I. El-Dessouky, Synthesis, structural characterization, in vitro antimicrobial and anticancer activity studies of ternary metal complexes containing glycine amino acid and the anti-inflammatory drug lornoxicam, J Mol Struct.. 1082: (2015) 12-22.

[42] S. Shukla, A. P. Mishra, Non-isothermal degradation-based solid state kinetics study of copper (II) Schiff base complex, at different heating rates, J Therm Analy Calorim., 107: (2012) 111-117.

[43] F. Karipcin, B. Dede, Y. Caglar, D. Hur, S. Ilican, M. Caglar, Y. Sahin, A new dioxime ligand and its trinuclear copper (II) complex: Synthesis, characterization and optical properties, Opt Commu., 272: (2007) 131-137.

[44] M. M. Rashad, A. M. Hassan, A. M. Nassar, N. M. Ibrahim, A. Mourtada, A new nano-structured Ni (II) Schiff base complex: synthesis, characterization, optical band gaps, and biological activity, Apply Phys A., 117: (2014) 877-890. 


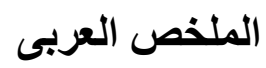

التوصيف الهيكلي ،الدراسات الحرارية ، الفلورسينس والخصائص الضوئية لمشتقات الكربونيل المعدنية

$$
\text { لقاعدة شيف }
$$

\section{أمل عادل عوض، عبد الفتاح نصار، أميمه أحمد مصطفي \\ كليه البنات جامعه عين شمس , كليه البنات جامعه عين شمس}

نم تحضير سلسله من المتر اكبات [Mo $2 \mathrm{O}_{5}(\mathrm{CO})$ L] . $\mathrm{H}_{2} \mathrm{O}$ الليجاند

6,6'-(([1,1'-biphenyl]-4,4'diylbis(azaneylylidene))bis(methaneylylidene))bis(2,4dichloro- phenol) $\mathrm{H}_{2} \mathrm{~L}$.

لقد تم توصيف قو اعد شيف ومتر اكباتها بواسطه قياس التحليل العنصري، طيف الاشعه تحت الحمر اء، طيف الرنين النووي المغناطيسي ، طيف الكتله. أظهرت الدراسات المغناطيسية للمتر اكبات الموليبننيوم و التنجستن خصائص ديامغناطيسية و منر اكب الكروم لله خاصيه بار امغناطيسية. وايضا أجريت در اسة التحليل الوزني

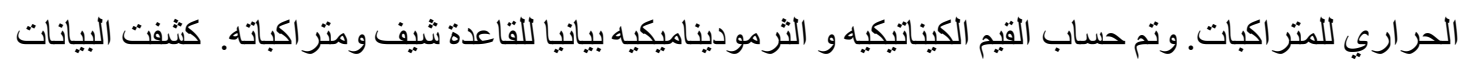

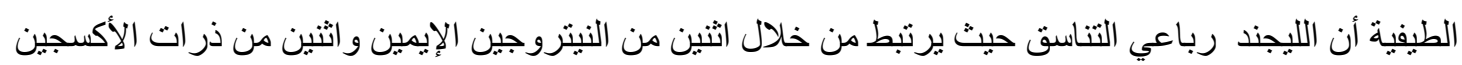

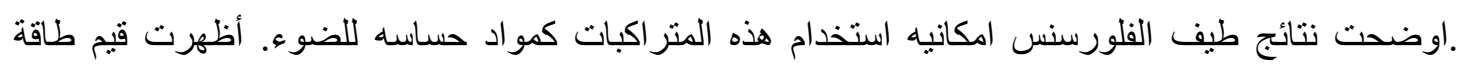
فجوة (Eg) النطاق البصري للمنر اكبات أنه يمكن استخدام هذه المركبات كأثباه موصلات. 